\title{
Heat absorbing glass from rice husk ash for a sustainable environment
}

\author{
G. Berkin \\ Faculty of Architecture, T.C. Halic University, Turkey
}

\begin{abstract}
Rice growing countries are having environmental problems eliminating large amounts of rice husks. rice husks are the by-product of rice paddy. Rice husks are burnt in the boilers for processing paddy. About 20 million tones of rice husk ash are produced annually. This is a great environmental threat causing damage to the land and the surrounding area in which it is dumped. Lots of ways are being thought of for disposing rice husk ash by recycling it into building materials. Rice husk ash consists of 95\% silica and 5\% metal ions (iron, aluminum, etc.) The particle size is 25 microns. This material is being used as a refractory brick as it has a good radiation absorption property. It has been used for insulation of molten metal in tundish and ladle in slab caster since it is an excellent insulator and as a pozzolana in the concrete. Silica is the major raw material in the glass composition. The glass industry obtains sand from sea coasts and riverbeds. This causes decline on the ecology of nektons and other organisms. Rice husk ash may be used instead of silica to prevent any sand erosion.

In this research rice husk ash has been used instead of sand in the glass composition. The result is a gray colored 'heat absorbing glass'. This study suggests that heat absorbing glass from rice husk ash helps stabilizing build environment and soil ecology by means of waste utilisation. Producing glass from this material helps to solve a number of environmental problems. Heat absorbing glass would enable better heat control in buildings and therefore this ecological synthesis would create a sustainable environment.
\end{abstract}

Keywords: rice husk ash, heat absorbing glass, sand, silica, iron, aluminum, refractory, insulator, radiation, sustainable environment. 


\section{Introduction}

Our planet faces several environmental threats mostly caused by unsustainable procurement and manufacturing of building materials and mismanagement of industrial and agricultural wastes. Great amounts of energy and natural resources are consumed not only to construct buildings but also to resolve the problems which emerge thereafter. The consequences of this are global warming, erosion in ecology, energy crises and adverse effects on world economy. Building, agriculture and industry sectors need to work more closely with each other to share know-how in order to cope with these problems. Architects, scientists and researchers should make more effort to design the building envelope from recycled and renewable materials. This would save energy and reduce environmental pollution and consequently contribute to sustainable development.

Sustainable building, as a term, is most commonly used to describe a building which is constructed according to sound ecological and environmental perspectives. The term Sustainable Development was first defined in 1987 by the World Commission on Environment and Development as a process "which meets the needs of the present without compromising the ability of the future generations to meet their own needs" Günther, et al. [1].

For a sustainable environment, the natural resources need to be protected. The building materials should be obtained from renewable and recycled raw materials. There are plenty of agricultural by-products, which are currently treated as waste. Disposing of these, especially if in large quantities, present a big challenge to many countries.

The environmentalist architect Stein states just after energy crisis years: "We became so entranced with the capability of mechanical plants that we no longer had to design buildings that were interconnected with the weather and climate around them" Stein [2]. In recent years, buildings have been increasingly designed as energy-efficient as possible, to avoid the undesired impacts on the environment. Heat loss from buildings is the biggest cause of energy consumption for both individuals and nations. Being the weakest building component in terms of heat insulation, windows have always been the main target for improving energy efficiency. A large number of researches have been carried out to improve insulation of windows. The conventional window glass is an extremely good absorber and emitter of thermal energy Tilley [3]. Swiss Architect Andrea Compagno suggests: "In normal float glass, thermal transmission is a critical factor in heat loss and thus also in associated heating expenditure and requirements" Compagno [4]. In the past, to enable the building components to become heat resistant, the pane numbers were increased and a buffer zone was created. More recently, the zones between glass panes were filled with inert gasses, as well as a low-e film being applied to reduce heat flow through windows. In cold climates, transparent thermal insulation material, made mostly from silica jells or capillary tubes (polymethylmethacrylate or polycarbonate) have been applied between the panes [1]. All of these applications have been successful in thermal resistance however, they were very 
expensive to manufacture. Therefore it can be concluded that despite their success, these solutions are neither cost nor environmentally friendly.

There is one other way of reducing energy while cooling and heating - the 'glass facade buildings' in particular - and that is to use heat absorbing glass instead of transparent ones. In this study rice husk ash has been added into glass composition instead of sand in order to promote the use of recycled agricultural by-products into building materials. The result is a heat absorbing glass made from a fine silica resource. Rice husk ash is obtained by burning rice husk (an agricultural by-product) in energy generating furnaces. As this material consists of high silica, it would pollute the environment if not disposed of properly.

The particle size of the material commonly used for glass (i.e. silica) is quite small and is mostly available at sea coasts and river beds. Excavation of these areas presents the risk of erosion and other undesired impacts on the ecology of nektons and other organisms. Therefore it can be said that using rice husk ash protects the environment in a much larger context by eliminating the need for excavating sea coasts and river beds.

\section{Properties of rice husk ash}

Rice husk is the by-product of rice paddy. In order to dispose of the waste, rice husk is burnt in boilers. They generate $13-15 \mathrm{MJ} / \mathrm{kg}$ power while being burnt in the furnaces. It is estimated that about 20 million tones of rice husk ash are annually discarded into waste disposal sites. This is not only a great waste but it also poses an environmental threat as there are potential risks of pollution for the surrounding land where it is discarded. There have been a number of studies to do this in an environmentally friendly way. One way of achieving this, is to recycle it into a building material. Rice husk ash has been previously used to produce several building materials such as pozzolana in concrete but also as insulation boards Mazlum [5].

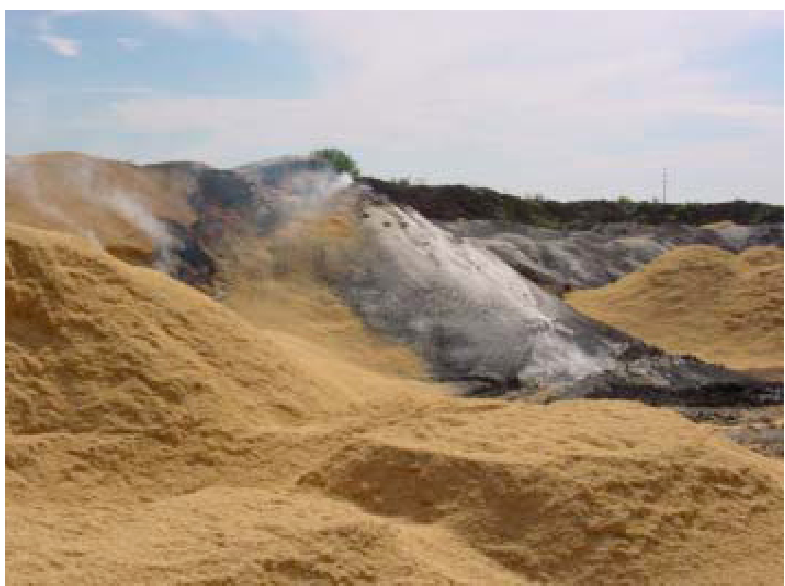

Figure 1: Burning rice husks outdoors. 
Rice husk ash consists of 95\% silica and 5\% metal ions (iron, aluminium, magnesium, potassium, etc.) Singhania [6].

The particle size of the rice husk ash is 25 microns. It can be used as raw material in the refractory bricks as it has good radiation absorption properties. It has been used for insulation of molten metal in tundish and ladle in slab caster as it is an excellent insulator. Rice husk ash is also added into concrete as pozzolana, as it makes the concrete durable to chemical attacks, protects it from abrasion and reinforcement corrosion, and increases the compressive strength by $10 \%$ [5]. The SQ analysis of elements in rice husk ash is presented in Table 1.

Table 1: $\quad$ Rice husk ash SQ analysis (Sisecam glass factory).

\begin{tabular}{|c|c|c|c|c|}
\hline Composition & Meas. C. & Spectrum & Density & Results \\
\hline & & & (kcps.) & (wt.\%) \\
\hline $\mathrm{SiO}_{2}$ & $\mathrm{SiO0}$ & $\mathrm{Si}-\mathrm{KA}$ & 511.9341 & 94.5 \\
\hline $\mathrm{K}_{2} \mathrm{O}$ & K 00 & $\mathrm{~K}-\mathrm{KA}$ & 9.6581 & 1.87 \\
\hline $\mathrm{P}_{2} \mathrm{O}_{5}$ & P 00 & $\mathrm{P}-\mathrm{KA}$ & 4.5012 & 0.934 \\
\hline $\mathrm{CaO}$ & $\mathrm{Ca} 00$ & $\mathrm{Ca}-\mathrm{KA}$ & 5.8148 & 0.910 \\
\hline $\mathrm{Al}_{2} \mathrm{O}_{3}$ & $\mathrm{Al} 00$ & Al-KA & 2.5424 & 0.480 \\
\hline $\mathrm{Fe}_{2} \mathrm{O}_{3}$ & Hv00 & Fe-KA & 8.3683 & 0.435 \\
\hline $\mathrm{MgO}$ & $\mathrm{Mg} 00$ & $\mathrm{Mg}-\mathrm{KA}$ & 0.4817 & 0.428 \\
\hline $\mathrm{MnO}$ & Hv00 & $\mathrm{Mn}-\mathrm{KA}$ & 2.0597 & 0.165 \\
\hline $\mathrm{SO}_{3}$ & S 00 & S -KA & 0.4325 & 0.0939 \\
\hline $\mathrm{Na}_{2} \mathrm{O}$ & $\mathrm{Na} 00$ & $\mathrm{Na}-\mathrm{KA}$ & 0.0377 & 0.0860 \\
\hline $\mathrm{WO}_{3}$ & Hv00 & $\mathrm{W}-\mathrm{LB} 1$ & 0.3266 & 0.0140 \\
\hline $\mathrm{ZnO}$ & Hv00 & $\mathrm{Zn}-\mathrm{KA}$ & 0.9455 & 0.0120 \\
\hline
\end{tabular}

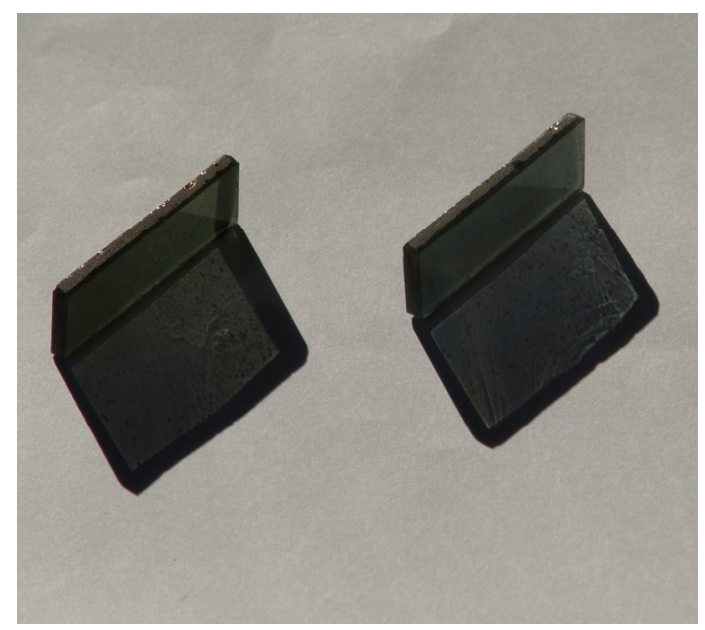

Figure 2: Heat absorbing glass from rice husk ash. 


\section{The melting phase of rice husk ash glass}

For this study, standard float glass composition (soda-lime-silica) was used to form the heat absorbing glass from rice husk ash. The glass composition was prepared in Sisecam Glass Factory Research Laboratories in Istanbul. The batches were placed into jars and then mixed for one hour. Rice husk ash was used in the glass composition $69 \%$ in weight instead of silica sand.

The glass batch was kept in the pre-heated oven in $1400{ }^{\circ} \mathrm{C}$ for four hours. The result was a grey coloured heat absorbing glass. (In this particular case, the iron oxides which were present in the rice husk ash content might have formed this colour.) The sample was then cut into $4 \mathrm{~mm}$ thick panels and polished. Their solar and light transmissions were then tested. In the Figure 3, the graph shows the transmittance and wavelength values of the rice husk ash glass.

3 SAMPLES

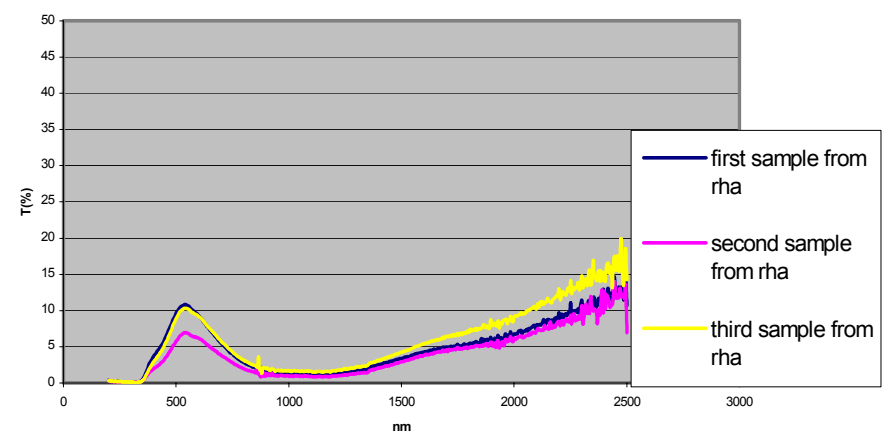

Figure 3: Light transmission graph of rice husk ash glass.

Our findings suggest that heat absorbing glass from rice husk ash is impervious in the ultra violet, visible and infra red region.

\section{Conclusion}

This study suggests that heat absorbing glass from rice husk ash helps stabilizing built environment and soil ecology by means of waste utilisation. Producing glass from this material helps to solve a number of environmental problems. Heat absorbing glass would enable better heat control in buildings and therefore this ecological synthesis would create a sustainable environment.

As rice husk ash is a very fine silica source, it would satisfy the demands of the glass industry which currently use sand for glass production. Using rice husk ash would reduce the need for excavating sand from riverbeds and coasts which undoubtedly causes erosion. Using this material to produce glass would help protect the environment in a larger scale. 
Heat absorbing glass from rice husk ash has low light and low infrared transmission, thus it could also be used to control excessive solar light in buildings and vehicles as it absorbs rays of sunlight. By using this product, buildings would spend less energy for air conditioning and thus emit less $\mathrm{CO}_{2}$ into the atmosphere.

Another advantage is that rice growing countries could dispose of this agricultural waste by recycling it into glass. It can therefore be concluded that heat absorbing glass from rice husk ash is a sustainable product for the environment.

Fertilizer (Silicon Based)

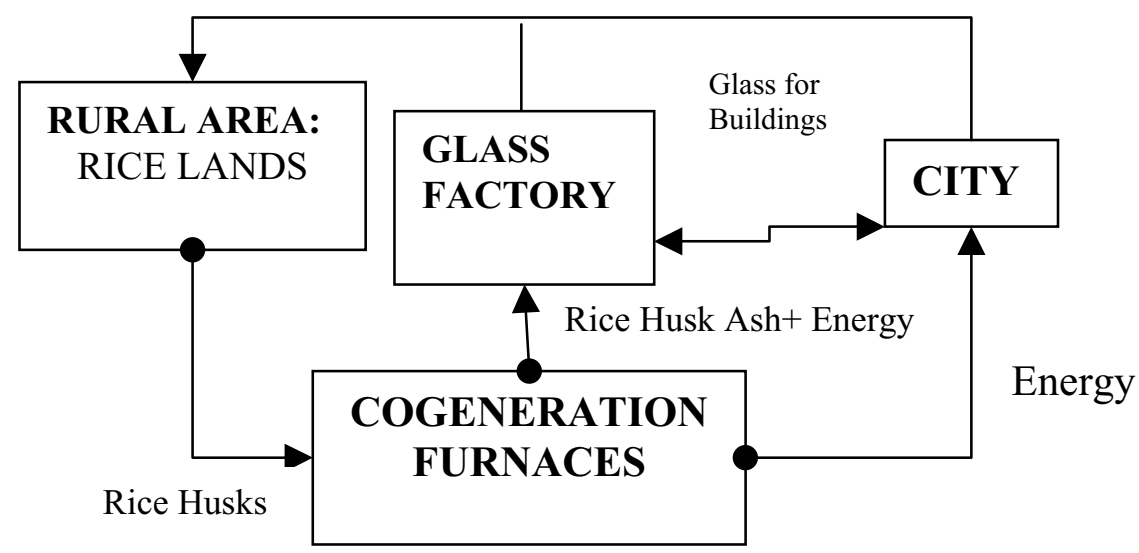

Figure 4: $\quad$ Silica cycle for a sustainable development.

\section{Suggestions}

Rice producing countries have the potential of environmentally friendly glass production. This silica cycle not only contributes to the sustainable development of rural and urban areas and the industry but also the national economy of these countries

\section{References}

[1] Günter-S.T., Abraham L.E., Fisher, T., Living Spaces-Ecological Building and Design. Slovenia: Könemann. pp. 12, 1998.

[2] Stein, R., Architecture and Energy. New York: Anchor Books. p. 46, 1978.

[3] Tilly, R., Colour and the Optical Properties of Materials. West Sussex: Wiley. p. 101, 2000.

[4] Compagno, A., Intelligent Glass Façades. Berlin: Birkhauser. p.13, 1995. 
[5] Mazlum, F., (1989). (The Pozzolonic Properties of Rice Husk Ash), PhD Thesis: Istanbul Technical University. p. 15, 1989.

[6] Singhania, N.P., Personal communication. April 18. 1998. 